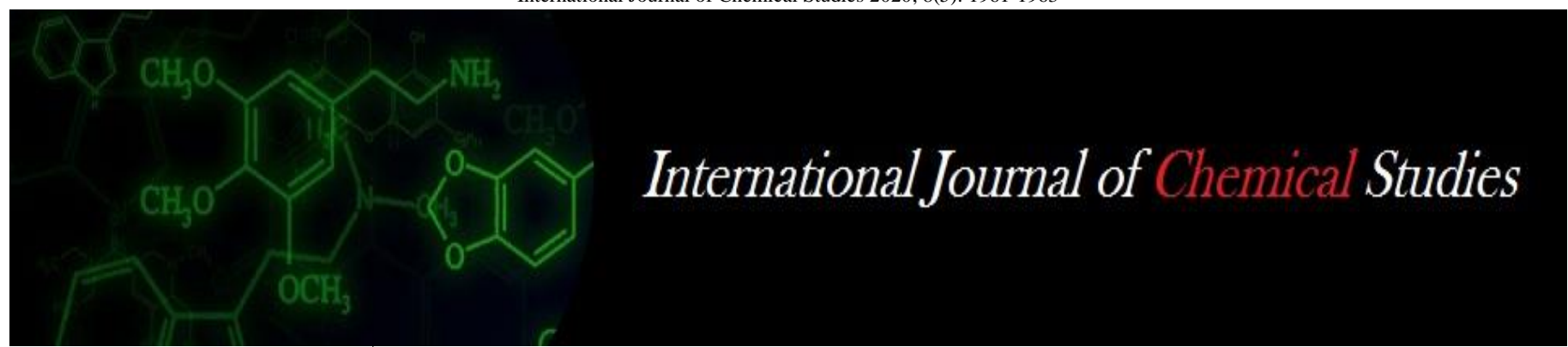

P-ISSN: 2349-8528

E-ISSN: 2321-4902

www.chemijournal.com

IJCS 2020; 8(5): 1961-1963

(C) 2020 IJCS

Received: 09-06-2020

Accepted: 15-07-2020

Mukesh Kumar Verma

Department of Agriculture,

S.G.R.R. University,

Pathribagh, Dehradun,

Uttarakhand, India

Kajal Mauraya

Department of Agriculture,

S.G.R.R. University,

Pathribagh, Dehradun,

Uttarakhand, India

Nikhilesh Negi

Department of Agriculture,

S.G.R.R. University,

Pathribagh, Dehradun,

Uttarakhand, India

AK Saxena

Department of Agriculture,

S.G.R.R. University,

Pathribagh, Dehradun,

Uttarakhand, India
Corresponding Author: Mukesh Kumar Verma Department of Agriculture, S.G.R.R. University, Pathribagh, Dehradun, Uttarakhand, India

\section{Effect of different concentration of soluble nutrients on yield and yield attributes of Blackgram (Vigna mungo) cultivar Pant urd-31 under Dehradun region (Uttarakhand)}

\author{
Mukesh Kumar Verma, Kajal Mauraya, Nikhilesh Negi and AK Saxena
}

DOI: https://doi.org/10.22271/chemi.2020.v8.i5aa.10588

\begin{abstract}
In order to investigate the effect of soluble nutrients on various yields and yield attributes of Blackgram crop, field experiment was carried out during kharif season (2019) at Research Block of S.G.R.R. University, Dehradun, Uttarakhand. The layout of experimental field was laid incompletely randomized block design with 10 treatments and 3 replications. The results indicated that among all the treatments, $\mathrm{T}_{7}$ [N: P: K (19:19:19) SOLUBLE AT 1.25\%] overall was found best for farmer point of view with respect to plant height $(56 \mathrm{~cm})$, number of pods per plant $(62.67)$, grain yield $(15.05 \mathrm{q}$ per ha), and straw yield (73.096 q per ha) at harvest. Results also indicated that harvesting index $(17.07 \%)$ also well for farmer point of view. Based on present investigation, it can be concluded that soluble fertilizers [N: P: K (19:19:19)] at $1.25 \%$ improved yield and yield attributes of Blackgram crop under present Agro-climatic conditions.
\end{abstract}

Keywords: Blackgram, plant height, no. of pod per plant, grain yield, straw yield, harvesting index

\section{Introduction}

Blackgram (Vigna mungo L.) is one of the important pulse crop in India. It belongs to leguminosease and sub family papilionaceae, and it secures unique position in Indian Farming System with an impressive use in human consumption or as well as improving soil fertility by fixing the nitrogen fixation in soil. India is the largest producer of Blackgram in pulses crops. Blackgram produce 3.06 million tonnes in 2018-19 and 2.25 million tonnes in 2019-20 (Ministry of agriculture and welfare) about 3.5 million ha of area with an average productivity of $5 \mathrm{q} / \mathrm{ha}$ (commoditiescontrol.com), which is low in order to potential of crop. The Hon'ble Prime Minister of India always focus doubling of farmer income that direct or indirect indicating the increment of crop productivity and soil fertility by using proper agronomical practices, judicious use of fertilizers and increased efficiency.

At the time of India independence agriculture sector of India had the biggest share in the Gross Domestic Product (GDP), but year by year its contribution goes on declining and currently, it contributes only about 17 percent of Indian GDP at current prices. Lack of technical knowledge in farmer with wider gap to researcher leaded to lower productivity of blackgram. It is necessary to create easy or low cost of production technique which farmer can adopt to increase the production of blackgram at short interval of time. Apart from other agronomical management practices, imbalanced plant nutrition is the major constraint for higher crop productivity. Blackgram being a leguminous crop, require adequate amount of fertilizer for growth and development of plant.

Effect of foliar application of nutrient management on yield and yield attributes of blackgram Dharmendra meena, et al., (2017) ${ }^{[3]}$. A.H. Mir et al., (2013) ${ }^{[4]}$ and M.U. Kulsum et al., (2007) [5] observed different level of phosphorus and nitrogen effect the growth and yield of blackgram respectively. Therefore, the aim of the present study was to investigate the effect of different concentration of soluble nutrient on various yield and yield attributes of Blackgram.

\section{Materials and Methods}

The present study was carried out during kharif season (2019) at Research Block of S.G.R.R. 
The present study was carried out during kharif season (2019) at Research Block of S.G.R.R. University Dehradun, Uttarakhand. Field experiment were conducted under sandy loam soil and laid out in completely randomized block design with 10 treatments and 3 replications. The recommended dose of fertilizers i.e., 20:40:40 kg per ha $\mathrm{N}, \mathrm{P}_{2} \mathrm{O}_{5}$ and $\mathrm{K}_{2} \mathrm{O}$, respectively, were applied according to the farmer's practice. The different concentration of soluble fertilizer were applied according to experiment into two time, $1^{\text {st }}$ after 20 day after sowing and $2^{\text {nd }} 40$ day after sowing (DAS). The experiment included treatments $\mathrm{T}_{1}$ (Control), $\mathrm{T}_{2}$ (Recommended Dose of Fertilizer), $T_{3}(\mathrm{~N}: \mathrm{P}: \mathrm{K}(9: 19: 19)$ Soluble @ 0.25\% + Urea 1\%), $\mathrm{T}_{4}(\mathrm{~N}: \mathrm{P}: \mathrm{K}(9: 19: 19)$ Soluble @ 0.5\% + DAP 1\%), Ts (N: P: K (9:19:19) Soluble @ 0.75\% +Urea 0.5\% +DAP 0.5\%), T (N: P: K (9:19:19) Soluble @ 1\% +Urea 0.5\%), T7 (N: P: K (9:19:19) Soluble@1.25\%), T8 (N:P:K (9:19:19) Soluble @ $1.5 \%), \mathrm{T}_{9}$ (N: P: K (9:19:19) Soluble @ 1.75\%), T10 (N: P: K (9:19:19) Soluble@2\%).Seeds were sown during second week of august with spacing $30 \times 10 \mathrm{~cm}$. The crop was harvested during first week of November. The growth parameters viz.; plant height, no. of pod per plant, whereas yield parameters viz.; seed yield, straw yield, biological yield were observed after harvesting of the crop with following procedures:

The height of the five tagged plants was recorded from the ground level to the tip of the plant. Then, average height was computed.

Five plants were randomly selected the removed border rows of experimental plot. Sun dried tagged plants were dried also in an oven at $65^{\circ} \mathrm{C}$ temperature. The dry weight of plant was recorded according to experimental treatments on weighing balance.

Count Pod of five tagged plants of each experimental plot, after threshing recorded the average seed yield of each experimental plot then converted into quintals per hectare.

\section{Results and Discussion \\ Plant height (cm)}

Plant height is an important yield contributing factor and directly relative to the production of straw yield. Analysis of variance showed significant variation at 5 percentage on plant height where treatment, $\mathrm{T}_{6}$ [N: P: K (19:19:19) SOLUBLE @ $1 \%+$ Urea $1 \%$ ] recorded the tallest plant $(62.66 \mathrm{~cm})$ at harvest which was statistically different from other level of soluble N: P: K (19:19:19). At these stages, the shortest plant $(53.00 \mathrm{~cm})$ was noticed from the treatment $\mathrm{T}_{4}$ (table-1).

Results indicated that at soluble (N: P: K) $1 \%$ +urea .5\% under rainfed condition showed maximum plant height which might be the positive effect of soluble fertilizer [N: P: K $(19: 19: 19)+$ Urea] as it increased the vegetative growth with proper root development over the other treatments. This finding was similar to Kasarla Chaithanya et al., (2019) ${ }^{[6]}$.

\section{Number of pod plant ${ }^{-1}$}

The number of grain per plant is the most potential factor in pulses crop and it directly related to yield. A significant data variation was found on the number of grains per plant due to effect of different level of soluble fertilizer. The maximum no. of grain per plant (65.34 and 62.67) were showed (Table 1) under treatment $T_{9},[N: P: K(19: 19: 19)$ SOLUBLE AT $1.75 \%$ ] and $\mathrm{T}_{7}$ [N: P: K (19:19:19) SOLUBLE @ 1.25\%], whereas lowest number (39.67) was observed in $\mathrm{T}_{5}[\mathrm{~N}: \mathrm{P}: \mathrm{K}$ soluble@0.75\%+Urea.5\% +DAP 0.5\%].

\section{Grain yield (q ha-1)}

A significant variation was found on grain yield of blackgram with different levels of soluble fertilizer. Grain yield (15.05 $\mathrm{q} / \mathrm{ha})$ was the highest in treatment $\mathrm{T}_{7}[\mathrm{~N}: \mathrm{P}: \mathrm{K}(19: 19: 19)$ SOLUBLE@1.25\%]. Similarly, $\mathrm{T}_{5}$ [N: P: K (19:19:19) SOLUBLE @ 0.75\%+ UREA 0.5\%+ DAP 0.5\%] gave the comparatively lower grain yield $(10.14 \mathrm{q} / \mathrm{ha})$ which was also statistically different from other treatments (Table-1). This findings was similar to M.U. Kulsum et al., (2007) ${ }^{[5]}$.

\section{Straw yield (q ha-1)}

Straw yield affected significantly due to the effect of different doses of soluble fertilizer. Among the soluble fertilizer N: P: K (19:19:19) doses, the highest straw yield (95.67 q/ha) obtained from the application of soluble fertilizer N: P: K (19:19:19)@ $1.75 \%$ is significant higher at compare to other treatment. Treatment $\mathrm{T}_{1 \text { and } 7}$ [CONTROL (79.94 q/ha) and $\mathrm{N}$ : P: K (19:19:19) SOLUBLE @ 1.25\% (73.09 q/ha)] also give significant straw yield as compare to other treatment except $\mathrm{T}_{9}$ (Table 1). These findings were similar to Dharmendra meena et al., (2017) ${ }^{[3]}$ and Singh et al., (2009) ${ }^{[7]}$.

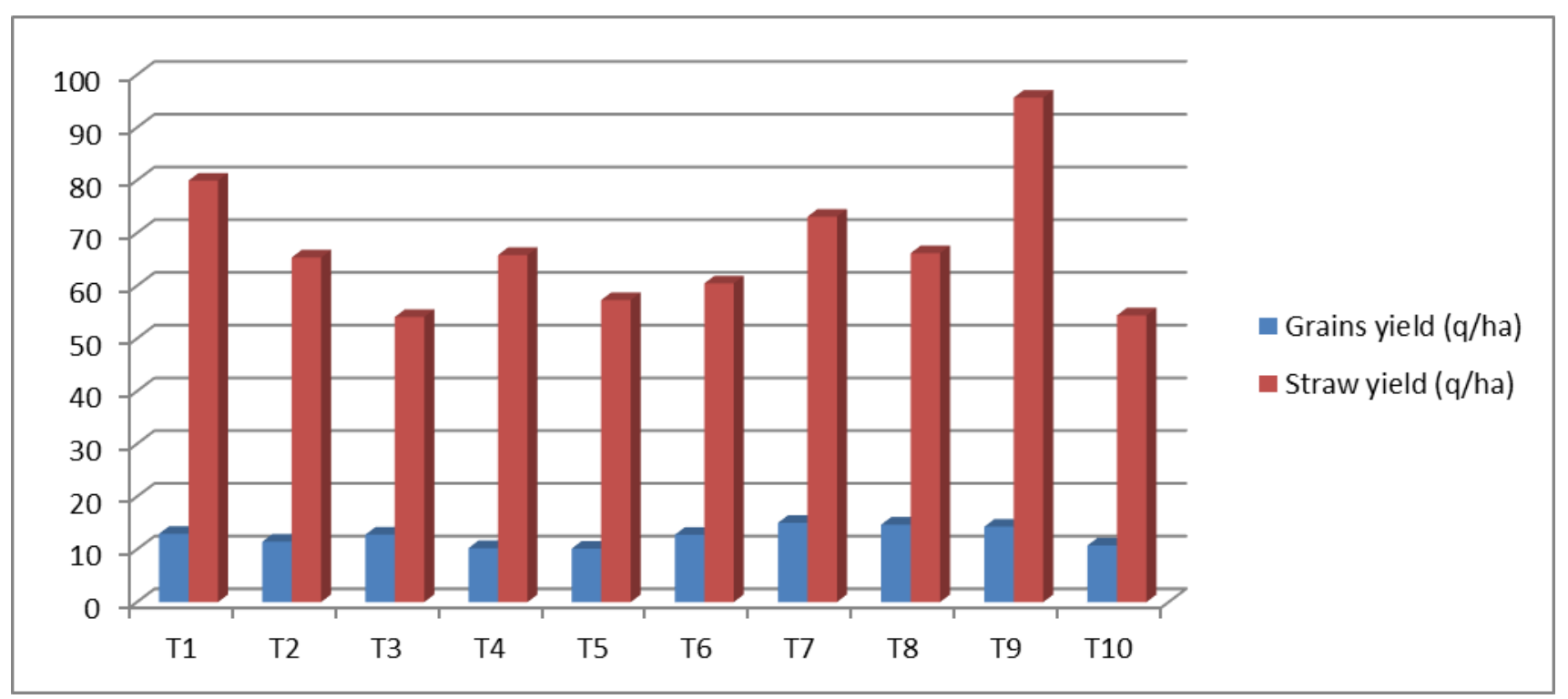

Fig 1: Effect of soluble nutrient on grain yield and straw yield. 


\section{Harvesting index $(\%)$}

The maximum Harvesting Index (19.20\%) was obtained from the application of soluble fertilizer N: P: K soluble @ $0.25 \%$ +Urea $1 \%$ in $\mathrm{T}_{3}$ which was statistically identical with the application of soluble fertilizer N:P:K soluble at 1.5\%, N:P:K soluble@ @ $1 \%$ +Urea $0.5 \%$ and N: P: K soluble @ $1.25 \%$ $\left(18.17 \%, 17.45 \%\right.$, and 17.07 respectively. Treatment, $\mathrm{T}_{9}(\mathrm{~N}:$ $\mathrm{P}$ : K soluble at $1.75 \%$ ) gave the lowest $\mathrm{HI}(13.01 \%)$. The result suggested that all the treatments of soluble fertilizer were efficient to produced significantly (Table 1).This might be due to the contribution of soluble fertilizer $\mathrm{N}$ : P: K $(19: 19: 19)$ to produce higher vegetative growth.

\section{Conclusion}

From the study, it revealed that on the bases of farmer living status the application of soluble fertilizer N: P: K (19:19:19) (a $1.25 \%$ is the best dose for achieving the higher return from the black gram. We are also advice the farmer to use soluble nutrient in the hand of solid nutrient form to decrease the cost of cultivation and earn more net return.

Table 1: Effect of soluble nutrient on various yield and yield attributes of Blackgram.

\begin{tabular}{|c|c|c|c|c|c|c|}
\hline \multicolumn{2}{|c|}{ Treatment } & Height & Pods/Plant & Grain yield & Straw yield & harvesting index \\
\cline { 2 - 7 } & & $(\mathbf{c m})$ & $(\mathbf{n o .})$ & $(\mathbf{q}$ per ha) & $(\mathbf{q}$ per ha) & $(\%)$ \\
\hline T1 & Control & 61.00 & 55.67 & 12.95 & 79.94 & 13.94 \\
\hline T2 & RDF & 60.67 & 55.34 & 11.46 & 65.36 & 14.91 \\
\hline T3 & N:P:K soluble @ 0.25\% +Urea 1\% & 60.00 & 52.33 & 12.81 & 54.08 & 19.20 \\
\hline T4 & N:P:K soluble @ 0.5\% +DAP 1\% & 53.00 & 43.67 & 10.23 & 65.83 & 13.46 \\
\hline T5 & N:P:K soluble @ 0.75\% +Urea 0.5\% +DAP 0.5\% & 53.33 & 39.67 & 10.14 & 57.27 & 15.02 \\
\hline T6 & N:P:K soluble @ 1\% +Urea 0.5\% & 62.67 & 52.00 & 12.78 & 60.46 & 17.45 \\
\hline T7 & N:P:K soluble @ 1.25\% & 56.00 & 62.67 & 15.05 & 73.09 & 17.07 \\
\hline T8 & N:P:K soluble @ 1.5\% & 57.00 & 58.00 & 14.69 & 66.17 & 18.17 \\
\hline T9 & N:P:K soluble @ 1.75\% & 61.67 & 65.34 & 14.30 & 95.67 & 13.01 \\
\hline T10 & N:P:K soluble @ 2\% & 61.33 & 52.67 & 10.75 & 54.38 & 16.52 \\
\hline & CD (0.05\%) & 4.96 & 3.46 & 1.25 & 3.86 & 0.24 \\
\hline
\end{tabular}

\section{References}

1. Ministry of agriculture and welfare (https://farmer.gov.in/SucessReport)

2. http://www.commoditiescontrol.com/eagritrader/commod ityknowledge/blackgram/blackgram1.htm.

3. Dharmendra meena, Chandra bhushan, Anil Shukla. Studies on foliar application of nutrients on nodulation, yield attributes, yields and quality parameters of uradbean. Ann. Agric. Res. 2017; 12(1):411-414.

4. Mir AH, Lal SB, Salmani M, Abid M, khan I. Studies on growth, yield, and nutrient content of Blackgram as influenced by levels of phosphorus, solubilizing bacteria. SAARC J Agri. 2013; 11(1):1-6.

5. Kulsum MU, Baque MA, Karim MA. Studies on effects of different nitrogen levels on the morphology and yield of Blackgram. Journal of Agronomy. 2007; 6(1):125-130.

6. Kasarla Chaithanya, Rajesh S, Suresh BG, Sanjay Kumar, Lal GM. Studies on assessment of genetic variability parameter in black gram germplasm. Int. J Curr. Microbiol. App. Sci. 2019; 8(8):1853-1860.

7. Singh, Anjali Chandra, Singh RK, Singh MK. Integated nutrient management in black gram (Vigna mungo) under rainfed conditions. International Journal of Tropical Agriculture. Serials publications. 2009; 27(3-4):541-544. 